\title{
Political Interference in Clinical Programs: Lessons From The U.S. Experience
}

Peter A. Joy*

\section{INTRODUCTION}

Around the world, law school clinics are playing an increasingly important role in training future lawyers and providing access to the courts for traditionally underrepresented individuals and groups. Today, there are law school clinical programs on the continents of Africa, Asia, Australia, Europe, North America and South America, and each year brings clinical education to more countries - most recently Japan. ${ }^{1}$ In the United States, which has had clinical programs for several decades, student practice rules in every jurisdiction permit law students to represent clients in and

* $\quad$ Professor of Law 8 Director, Criminal Justice Clinic, Washington University School of Law in St. Louis.

1 Japan may be the most recent country to initiate clinical legal education programs, following the adoption of a new system of graduate professional legal education as part of reforms "for the purposes of 'clarifying the role to be played by justice in Japanese society in the 21 st century and examining and deliberating fundamental measures necessary for the realization of a justice system that is easy for the people to utilize, participation by the people in the justice system, achievement of a legal profession as it should be and strengthening the functions thereof, and other reforms of the justice system, as well as improvements in the infrastructure of that system." Recommendations of the Justice System Reform Council - For a Justice System to Support Japan in the 21st Century - at http://www.kantei.go.jp/foreign/ judiciary/2001/0612report.html (last visited June 3,
2005) (quoting article 2, Paragraph 1 of the Law concerning Establishment of the Justice System Reform Council) [hereinafter Justice System Reform Recommendations]. The new law schools are a cornerstone of the reforms designed to "bridge between theoretical education and practical education," and to provide law students with the opportunity to acquire the specialized legal knowledge, lawyering skills, and professional values "necessary for solving actual legal problems." Id. at ch. III, pt. 2. Some of the new law schools have already instituted clinical courses in which law school faculty and students provide legal assistance to clients. See, e.g., Takao Suami, Clinical Legal Education and the Foundation of Japanese Law Schools in the Context of Judicial System Reform (April 15, 2005) (unpublished manuscript, on file with author) (describing the judicial reforms in Japan the importance of clinical legal education for Japanese law schools). 
out of court, ${ }^{2}$ effectively making them "student-lawyers." ${ }^{3}$ Through their representation of clients, law students in clinical programs experience the practice of law and learn the important lawyering skills and professional values needed to be competent, effective lawyers. ${ }^{4}$ The student-lawyers in clinical programs, and their supervising clinical faculty, also experience issues that other lawyers representing poor and sometimes unpopular clients face - interference with the selection and representation of clients designed to deny legal services in some matters to those unable to afford to hire other lawyers. ${ }^{5}$

For more than thirty-five years, clinical programs in the United States have faced political interference and attacks by elected officials, business groups, and others for providing poor people access to the courts on matters including redress of racial discrimination, prisoner rights litigation, death penalty cases, and environmental issues. In each instance, the political interference has sought to subvert the legal process by preventing clinical programs from representing their clients rather than having the courts rule on the legal merits of their clients' claims. The political interference with law school clinic client representation also appears to be part of the broader

2 In 1969, the American Bar Association (ABA) promulgated a Model Student Practice Rule to facilitate the growth of clinical courses in United States law schools. See Proposed Model Rule Relative to Legal Assistance by Law Students, A.B.A. Rep. 290, 290 (1969) [hereinafter Proposed Model Rule]. The dual jurisdictional system of separate state courts and federal courts in the United States results in each separate jurisdiction having the power to regulate the student practice of law before the courts within the jurisdiction. The high court in each state, usually called the state supreme court, regulates the practice of law before all the trial and appellate courts within the state. In contrast, in the federal system each individual federal court has the authority to adopt its own student practice rule that applies only to those clinical students who appear before it. See George K. Walker, A Model Rule for Student Practice in the United States Courts, 37 WASH. 8 LEE L. REV. 1101, 1106-13 (1980). All fifty states, plus the District of Columbia and Puerto Rico, have adopted student practice rules. See Joan W. Kuruc E Rachel A. Brown, Student Practice Rules in the United States, 63 B. EXAMINER, No. 3, at 40, 40-41 (1994). In addition, almost every federal court has adopted some form of a student practice rule or permits law students to appear upon motion with the court. See Jorge deNeve, Peter A. Joy E) Charles D. Weisselberg, Submission of the Association of American Law Schools to the Supreme Court of the State of Louisiana Concerning the Review of the Supreme Court's Student Practice Rule, 4 CLINICAL L. REV. 539, 549-50 (1998).

3 In the United States, law students must be admitted to practice under a state jurisdiction's or federal court's student practice rule or order before they are legally and ethically able to provide legal representation to clients or claim to be "student-lawyers." Clinical programs often enroll other students who are not admitted to the limited practice of law under a student practice rule, but these clinical students must function as lawyer assistants or law clerks and not as studentlawyers authorized to provide legal advice and other legal representation to clients. See Peter A. Joy $\mathbb{E}$ Robert R. Kuehn, Conflict of Interest and Competency Issues in Law Clinic Practice, 9 CLINICAL L. REV. 493, 497 (2002).

4 A study by the ABA identified ten fundamental lawyering skills and four fundamental professional values essential for the competent, professional representation of clients. See SECTION ON LEGAL EDUC. AND ADMISSIONS TO THE BAR, AMERICAN BAR ASS'N, LEGAL EDUCATION AND PROFESSIONAL DEVELOPMENT - A CONTINUUM 138-41(1992) [hereinafter MacCrate Report]. The ten fundamental lawyering skills are: problem solving; legal analysis and reasoning; legal research; factual investigation; communication; counseling; negotiation; dispute resolution; organization and management of legal work; and resolving ethical dilemmas. See id. at 138-40. The four fundamental values of the legal profession are: providing competent representation; promoting justice, fairness, and morality; improving the profession; and fostering professional self-development. See id. at 140-41.

5 Robert R. Kuehn 8 Peter A. Joy, An Ethics Critique of Interference in Law School Clinics, 71 FORDHAM L. REV. 1971, 1974 (2003). The interference is typically designed to prevent the bringing of certain types of cases, such as environmental or civil rights legal claims, or bringing or defending lawsuits against certain defendants, such as businesses or governmental entities, more that focusing on denying legal representation of certain clients. See infra Part IB. The net effect of this interference, however, is such that it would deny those clients unable to afford to pay for legal assistance access to the courts. 
attacks on public interest lawyers and other lawyers representing clients in disputes with governmental entities, business interest, or other more powerful adversaries.

The extent to which clinical programs in other countries currently face or will face political interference in the representation of their clients is unclear. Even if political interference in clinical programs is not yet a pressing issue in some countries, an analysis of political interference may be helpful to law faculty currently teaching in or working to implement clinical programs for at least three reasons. First, from a comparative law perspective, understanding the nature of political interference in clinical programs outside of one's own country may afford useful insights to foster critical thinking about the relationship between the role of lawyers in providing access to the courts and the role of clinical legal education in acculturating law students to the legal profession. Second, the increasing internationalisation of law makes understanding the experiences in other countries vital to being a legal educator in the 21 st century, and understanding clinical legal education issues in other countries makes clinical educators more effective teachers. Finally, understanding the types of political interference and the responses to political interference in the United States may prove useful to clinical faculty in other countries experiencing similar attacks on their work in clinical courses.

This article reviews the history of political interference in clinical programs in the United States, considers the attacks on clinical programs in the context of attacks on other lawyers representing the poor or other marginalized clients, and draws lessons from the experience in the United States that may be helpful to clinical programs in other countries. ${ }^{6}$ With the spread of clinical teaching throughout the world, it is likely that law faculty teaching clinical courses in other countries may encounter the types of political interference with client and case selection experienced by their colleagues in the United States.

Part I of this article examines the access to justice mission of clinical legal education in the United States and briefly traces the history and types of political interference in law school clinical programs. It also discusses the ethical obligations of lawyers to represent unpopular or controversial clients or causes, and considers how the attacks on clinical programs interfere with a lawyer's ethical obligation to act independently of third-party interests.

Part II examines the relationship between access to justice and the attacks on the major sources of public interest lawyers in the United States. Part II contends that access to the courts is a cornerstone principle for the rule of law, and access to the courts depends on having the assistance of a lawyer. Part II draws a connection between the political interference in clinical programs and other attacks on public interest lawyers.

Part III analyzes the legacy of political interference on clinical programs. It discusses the effects of both the highly publicized attacks on clinical programs and the more frequent questions concerning clinical programs' choices of clients and cases. It argues that the breadth of political interference in clinical programs in the United States indicates that any clinical program may be

6 This article builds upon some ideas I have explored in previously published articles. See generally Peter A. Joy $\mathcal{E}$ Charles D. Weisselberg, Access to Justice, Academic Freedom, and Political Interference: A Clinical Program Under Siege, 4 CLINICAL L. REV. 531 (1998) (discussing the nexus between academic freedom, access to the courts, and political interference with clinical programs); Peter A. Joy, Political Interference with Clinical Legal Education: Denying Access to Justice, 74 TULANE L. REV. 235 (1999) (examining the role of law school clinics in providing access to justice and attacks on law school clinics); Kuehn $\mathbb{E}$ Joy, supra note 5 (examining the history and ethics of political interference in law school clinics). 
targeted even if the clinical faculty believe that they are taking non-controversial cases. Part III also questions whether political interference in clinical programs will be as great an issue in those countries that make legal assistance in civil cases more available to persons who are unable to afford to hire a lawyer than does the Unites States.

The article concludes that law school clinical programs can model the highest ideals of the legal profession by evaluating potential cases on the legal merits and pedagogical value and not with a concern for whether or not the case or client may be controversial.

\section{INTERFERENCE IN LAW SCHOOL CLINIC CASE AND CLIENT SELECTION}

\section{A. Access to Justice Mission of Clinical Legal Education in the United States}

Clinical legal education in the United States has existed for more than one hundred years in some form, and it has its roots in law students setting up volunteer legal aid bureaus or dispensaries to assist persons unable to afford to hire attorneys. ${ }^{7}$ By the early 1950 s, clinical pedagogy was becoming accepted both as a valuable means for exposing "the law student to actual problems ... [of] actual people who are in actual trouble" 8 and as a way of advancing "equality of justice" by helping to develop throughout the country "an adequate system of legal aid offices." From its earliest development, clinical legal education in the United States has included an access to justice mission.

Clinical legal education developed at a much more rapid pace starting in the 1960s, and the social justice mission of providing access to the courts remained a primary goal. Starting in 1959 and continuing through 1978, the Ford Foundation provided approximately $\$ 13$ million in grants and other assistance to over 100 law schools through a program which was eventually known as the Council on Legal Education for Professional Responsibility (CLEPR). ${ }^{10}$ William Pincus, who directed CLEPR, stressed that access to the courts or "a concern with justice for all" was a

$7 \quad$ The first clinical programs in the United States were started in the late 1890s and early 1900s as noncredit, volunteer legal aid bureaus or legal dispensaries run by law students at a small number of law schools. See John S. Bradway, The Nature of a Legal Aid Clinic, 3 S. CAL. L. REV. 173, 174 (1930); William V. Rowe, Legal Clinics and Better Trained Lawyers A Necessity, 11 ILL. L. REV. 591, 591 (1917).

8 Robert G. Storey, Law School Legal Aid Clinics: Foreward, 3 J. LEGAL EDUC. 533, 533 (1951).

9 Id. at 534. A 1951 study of clinical legal education programs identified twenty-eight clinics run by law schools, independent legal aid societies, or public defender offices. See Quintin Johnstone, Law School Clinics, 3 J. LEGAL EDUC. 535, 535 (1951). Most of the law schools offered clinics as elective courses or extracurricular activities. See id. at 541-42.

10 From 1959 to 1965, the Ford Foundation made a total $\$ 500,000$ in grants to nineteen law schools through a program entitled the National Council on Legal Clinics (NCLC). See Orison S. Marden, CLEPR:
Origins and Programs, in COUNCIL ON LEGAL EDUCATION FOR PROFESSIONAL RESPONSIBILITY, CLINICAL EDUCATION FOR THE LAW STUDENT: LEGAL EDUCATION IN A SERVICE SETTING 3, 3 (1973) [hereinafter CLINICAL EDUCATION FOR THE LAW STUDENT]. In 1965, the Ford Foundation provided an additional $\$ 950,000$ to NCLC and renamed NCLC the Council on Education in Professional Responsibility, which was renamed the Council on Legal Education for Professional Responsibility (CLEPR) in 1968. See id. at 3, 6-7. The Ford Foundation granted an additional $\$ 11$ million to CLEPR, which awarded 209 grants equaling approximately $\$ 7$ million to 107 ABAapproved law schools from 1968 through 1978. See Margaret Martin Barry, Jon C. Dubin $\mathbb{E}$ Peter A. Joy, Clinical Education for This Millennium: The Third Wave, 7 CLINICAL L. REV. 1, 19 (2000). Other CLEPR support for clinical programs in law schools consisted of teaching materials, publications, and conferences. Id. at 19 n.74. 
challenge for the legal profession, ${ }^{11}$ and CLEPR funded clinical programs "to make unique and valuable contributions to the improvement of justice ... generally to those most in need and least able to afford them." 12 Orison Marden, Chair of CLEPR, explained that clinical legal education was important to expose law students to "public responsibilities" of the legal profession "to serve the poor as well as the rich, to work for reforms in the administration of justice, to be leaders in their communities." 13 Marden also noted that law students needed to learn that lawyers "should be willing to undertake the unpopular cause and to withstand with courage the disapproval of unthinking people when they do so."14

While CLEPR funded the growth of clinical programs with a purpose of providing legal assistance to those in need of lawyers, members of the bench and bar also supported the development of clinical legal education for access to justice reasons. ${ }^{15}$ To facilitate the spread of clinical legal education courses and to enable law students to provide legal representation to clients, the American Bar Association (ABA) promulgated the ABA Model Student Practice Rule in 1969. ${ }^{16}$ In creating the Model Student Practice Rule, the ABA stated that it had dual purposes to assist the bench and bar "in providing competent legal services for . . c clients unable to pay for such services and to encourage law schools to provide clinical instruction."17

In addition to CLEPR and the legal profession supporting an access to justice mission of clinical legal education in the 1960 s, one commentator noted that the growth of clinical programs was also motivated by "a desire on the part of a significant number of law students to help make the law serve the needs of the poor." 18 Other commentators echo the role of law student activism by attributing the growth of clinical legal education to the "social ferment of the 1960s," 19 and to the growing appreciation for the role of law in addressing "the fundamental problems of contemporary society." 20

Although CLEPR, the ABA, and law students all encouraged clinical programs to expand access to justice by representing poor and unpopular clients and causes, as clinical programs fulfilled this mission clinical faculty and their students found that some politicians, business interests, and university officials would sometimes attack law school clinics for their choices of clients and cases.

11 WILLIAM PINCUS, The Lawyer's Professional Responsibility, in CLINICAL LEGAL EDUCATION FOR LAW STUDENTS: ESSAYS 37, 38 (1980).

12 WILLIAM PINCUS, A Statement on CLEPR's Program, in CLINICAL LEGAL EDUCATION FOR LAW STUDENTS: ESSAYS, supra note 11, at 69, 70 .

13 Marden, supra note 10 , at 4.

14 Id.

15 For example, a former chief justice for the United States Supreme Court called on law schools to expand lawyering skills programs, and "provide society with people oriented and problem oriented counselors and advocates to meet the broad social needs of our changing world." See Warren E. Burger, The Special Skills of Advocacy: Are Specialized Training and Certification of Advocates Essential to Our System of Justice?, 42 FORDHAM L. REV. 227, 233-34 (1973). In addition, the United States Court of Appeals for the District of Columbia Circuit observed that law student practice "has been praised by members of the judiciary and encouraged by the Judicial Conference of the United States, and we have ample reason to extend our commendation." Jordan v. United States, 691 F.2d 514, 523 (D.C. Cir. 1982).

16 Proposed Model Rule, supra note 2, at 290. Colorado adopted a student practice rule in 1909, but only fourteen other states had student practice rules prior to 1969. See Michael D. Ridberg, Student Practice Rules, in CLINICAL LEGAL EDUCATION AND THE LAW SCHOOL OF THE FUTURE 223. 231-64 (Edmund W. Kitch ed., 1970).

17 Id.

18 Charles E. Ares, Legal Education and the Problem of the Poor, 17 J. LEGAL EDUC. 307, 310 (1965).

19 PHILIP G. SHRAG \& MICHAEL MELTSNER, REFLECTIONS ON CLINICAL LEGAL EDUCATION 1 (1998).

20 Arthur Kinoy, The Present Crisis in Legal Education, 24 RUTGERS L. REV. 1, 7 (1969). 
The following section briefly reviews the history and types of political interference with clinic case and client selection.

\section{B. History of Political Interference with Clinical Programs}

It is not unusual for clinical programs in the United States to be questioned by people outside of their law schools about the clients and cases the clinics represent. Law school alumni, legislators, university trustees, and opposing counsel or parties occasionally ask "why" a law school clinic is providing representation to certain clients asserting legal claims. ${ }^{21}$ These inquiries often incorrectly equate the clinic's client representation with law school approval of support for a client's views or activities, and misunderstand the basic principle that a lawyer's representation of a client is not an endorsement of the client's views. ${ }^{22}$ Usually, these inquires end once those raising the questions learn more about the clinic's teaching and service missions, and how the clinic faculty and students are fulfilling their ethical obligation to make legal services available to clients unable to afford lawyers or whose cause is controversial. ${ }^{23}$ When those questioning a clinic's representation have interests opposed to the interests of a clinic's client, however, the inquiries may turn into attacks on the clinic designed to interfere with or stop the clinic's representation of its clients or participation in specific types of cases.

It is unclear when the first attack and political inference in a clinical program took place, but the first documented instance of political interference appears to be attacks on the clinical program and faculty at the University of Mississippi in 1968. State legislators and some members of the legal community complained to university officials and the law school dean because of the clinical program's involvement in a school desegregation case brought by a local legal services office. ${ }^{24}$ In response to this pressure, the university dismissed the two law faculty involved in the civil rights litigation for refusing to cease their work with the legal services office. ${ }^{25}$ The faculty brought a lawsuit against the university, alleging that the university permitted other law faculty to engage in part-time law practice without any restrictions on the clients they could represent. The court agreed that the university impermissibly treated the two faculty members differently and unequally

21 See Joy $\mathbb{E}$ Weisselberg, supra note 6, at 531.

22 Ethics codes in the United States make it clear that a lawyer's representation of a client is not an endorsement of a client's views or actions. The high court in each state adopts the lawyer ethics rules, which are usually based on the ABA Model Rules of Professional Conduct. The ABA Model Rules provide: "A lawyer's representation of a client, including representation by appointment, does not constitute an endorsement of a client's political, economic, social or moral views or activities." MODEL RULES OF PROF'L CONDUCT R. 1.2(b) (2005) [hereinafter MODEL RULES]. The ABA Model Rules, adopted in 1983 and amended frequently, replaced the ABA Model Code of Professional Responsibility, which the ABA adopted in 1969 and amended in 1980. MODEL CODE OF PROF'L RESPONSIBILITY (1980) [hereinafter MODEL CODE]. More than forty states and the District of Columbia have adopted some version of the Model Rules. See STEPHEN GILLERS \& ROY D. SIMON, REGULATION OF LAWYERS: STATUTES AND STANDARDS 3
(2005). Most of the states that have not adopted some form of the Model Rules retain some version of the Model Code. Id. The Model Code provides: "The obligation of loyalty to his client applies only to a lawyer in the discharge of his professional duties and implies no obligation to adopt a person viewpoint favorable to the interest or desires of his client." MODEL CODE, supra, at EC-17.

23 "Legal representation should not be denied to people who are unable to afford legal services, or whose cause is controversial or the subject of popular disapproval." MODEL RULES, supra note 22, at R. 1.2 cmt. 5.

24 Francis B. Stevens $\mathcal{B}$ John L. Maxey, II, Representing the Unrepresented: A Decennial Report on PublicInterest Litigation in Mississippi, 44 MISS. L.J. 333, 345 (1973); Elizabeth M. Schneider Ef James H. Stark, Political Interference in Law School Clinical Programs: Report of the AALS Section on Clinical Legal Education, Committee on Political Interference 1 n.1 (1982) (unpublished report on file with author).

25 Trister v. Univ. of Miss., 420 F.2d 499, 500-02 (5th Cir. 1969). 
than other professors because they represented unpopular clients, and the court ordered the university to reinstate the faculty to their teaching positions. ${ }^{26}$ In reaching its decision, the court held that the state university could not "arbitrarily discriminate against professors in respect to the category of clients they may represent." 27

Soon after the political interference with the work of the clinical faculty at the University of Mississippi School of Law, the governor of Connecticut and members of the local legal community objected to the University of Connecticut law school clinic's representation of Viet Nam War protestors and other unpopular clients in the early 1970s. ${ }^{28}$ The attacks included the threat to end state funding for the law school, and the interference led to a proposal for a law school faculty committee to select cases for the clinic. ${ }^{29}$ A clinic professor requested and received an advisory ethics opinion from the ABA discussing the ethical propriety of the new client screening process. ${ }^{30}$ The ABA ethics opinion stated that case-by-case prior approval by a dean or faculty committee would interfere with the independent professional judgment of the clinical faculty and violate the ethical obligations of the dean and faculty members by placing the clinical faculty in a position to violate their ethical duties to clients. ${ }^{31}$ The ABA ethics opinion stated: "Acceptance of such controversial clients and cases by legal aid clinics is in line with the highest aspirations of the bar to make legal services available to all." 32 The law school discontinued the screening committee after the ABA issued its opinion. ${ }^{33}$

In the 1980s, there were several more attacks on clinical programs at the state-supported law schools in Colorado, Idaho, Iowa, and Tennessee seeking to prevent their clinical programs from filing lawsuits against the state or political subdivisions. In 1981, the governor of Colorado vetoed legislation that would have prohibited "law professors at the University of Colorado from assisting in litigation against a governmental unit or political subdivision." 34 The legislation was drafted after a law professor, working with students in a constitutional litigation seminar, filed a lawsuit challenging a nativity scene at the Denver City and County Building claiming that the nativity scene on government property was the government's endorsement of religion in violation of the United States Constitution. ${ }^{35}$

26 The court found a violation of the Equal Protection Clause of the United States Constitution because the law school had imposed on the clinical faculty "restrictions that are different and more onerous than those imposed upon other professors in the same category." Id. at 502.

27 Id. at 504

28 See Kuehn E Joy, supra note 5, at 1977 n.18 (citing emails from one of the clinical professors who was at the University of Connecticut at the time of the attacks on the clinic). The governor stated that the law school clinic was "nothing more than an agency designed to destroy our government and its institutions." Elizabeth M. Schneider, Political Interference in Law School Clinical Programs: Reflections on Outside Interference and Academic Freedom, 11 J.C. $\mathcal{E}$ U.L. 179, 184 (1984).

29 See Kuehn $\mathcal{E}$ Joy, supra note 5, at 1977 Ef n. 19.

30 ABA Comm. On Ethics \&ै Prof'l Responsibility, Informal Op. 1208 (1972).

31 Id.
32 Id.

33 See Kuehn Eु Joy, supra note 5, at 1977 Eु n. 21. Several years later, in the early 1980s, a high-ranking state official threatened to introduce legislation to limit the activities of the University of Connecticut Criminal Clinic after the clinic successfully challenged a provision of the Connecticut death penalty statute. Schneider 8 Stark, supra note 24, at 2 n.4.

34 Schneider, supra note 28, at 185-86; Schneider 8 Stark, supra note 24, at 2.

35 Schneider, supra note 28, at 185; Schneider Eु Stark, supra note 24 , at 2 n.3. The litigation resulted in a court order for the removal of a nativity scene at the Denver City and County Building, enjoining the inclusion of the nativity scene at the local government holiday display, and the awarding of costs and attorney fees to the plaintiff, who was represented by the University of Colorado law professor. Citizens Concerned for Separation of Church and State v. City and County of Denver, 481 F. Supp. 522, 532 (D. Colo. 1979), appeal dismissed, 628 F.2d 1289 (10th Cir. 1980), cert. denied, 452 U.S. 963 (1981). 
That same year, legislation was proposed in Idaho that would have prohibited the use of state funds for the representation of clients in litigation against the state or any political subdivision. ${ }^{36}$ This legislation, which was not adopted, was proposed after the University of Iowa College of Law's clinic successfully represented prisoners in litigation against the state. ${ }^{37}$ A year later, in 1982, the Idaho House of Representatives passed legislation that would have prohibited law faculty and students from participating in lawsuits against the state and would have banned "courses, clinics or classes in which a student assists or participates in any suit or litigation against the State, its agencies or its political subdivisions." 38 The legislation, which was defeated in the state senate, was introduced after the University of Idaho College of Law clinic challenged the proposed expansion of a highway. ${ }^{39}$

Although these early attacks on clinical programs were largely unsuccessful in limiting clinical programs' choice of clients and types of cases, in 1981 university officials in Tennessee imposed restrictions on the University of Tennessee College of Law suing the state after the clinic successfully brought a prisoner lawsuit against a state agency. ${ }^{40}$ The state attorney general filed a motion to deny the law clinic attorney fees arguing that it was illegal to transfer funds from one state agency to another without going through the legislative appropriations process. ${ }^{41}$ The fee dispute was resolved by directing the attorney fees to the legal services office that housed the clinic, ${ }^{42}$ but the university board of trustees required the clinic to separate from the legal services office and ordered that "no suits of significance shall be brought by the UT Legal Clinic on behalf of any litigant against the State." 43

Other early instances of political interference with law school clinic case and client selection include litigation in which government officials argued that it would be a conflict of interest for the state-supported Rutgers School of Law-Newark to continue to represent clients in any matter against the state and its political subdivisions, ${ }^{44}$ and legislation to cut-off state funding for the clinical program at the Arizona State University College of Law because of the clinic's representation of clients in lawsuits challenging ownership rights to riverbeds and the state prison system's failure to provide adequate law library materials to state inmates. ${ }^{45}$ The conflict of interest litigation failed against the clinical program at Rutgers School of Law-Newark in $1989,{ }^{46}$ but in the mid-1990s the Arizona legislature successfully inserted language in the state budget that prohibited

36 Schneider, supra note 28, at 185 \&ु n.30; Schneider $\mathcal{E}$ Stark, supra note 24 , at 1.

37 See Schneider, supra note 28 , at 185 n.30. See also Kuehn $\mathcal{E}$ Joy, supra note 5, at 1977 n.18 (citing an email from one of the clinical professors at the University of Iowa College of Law).

38 Schneider, supra note 28, at 186 \& n.33.

39 Id.

40 Memorandum from the Clinic Advisory Committee to the Faculty of the University of Tennessee College of Law 11-12 (May 22, 1981) (on file with author). In 1977, government officials successfully pressured the University of Tennessee's law clinic to withdraw from a lawsuit filed against the Tennessee Valley Authority (TVA) for air pollution violations, and the clinical faculty continued representation in his private capacity. See Kuehn Ef Joy, supra note 5 at 1979 n.32 (citing Telephone Interview with Dean Rivkin, Professor, University of Tennessee College of Law (Apr. 5, 2001)).
41 Memorandum from the Clinic Advisory Committee to the Faculty of the University of Tennessee College of Law, supra note 40, at 11-12.

42 Id.

43 Minutes of Meeting of Board of Trustees, University of Tennessee 6-7 (Sept. 25, 1981) (on file with author). See also Douglas A. Blaze, Déjà vu All Over Again: Reflections on Fifty Years of Clinical Education, 64 TENN. L. REV. 939, 960 Eु n.180 (1997); Julia P. Hardin, Polishing the Lamp of Justice: A History of Legal Education at the University of Tennessee, 1890-1990, 57 TENN. L. REV. 145, 193 (1990).

44 In re Executive Commission on Ethical Standards, 561 A.2d 542, 543-46 (N.J. 1989).

45 See Kuehn Eु Joy, supra note 5, at 1980 \&ु nn.39-40.

46 In re Executive Commission on Ethical Standards, supra note 44, at 549 . 
the Arizona State College of Law clinic from representing prisoners in any litigation against the state - a restriction the clinic has followed ever since. ${ }^{47}$

Conditions on government funding have been a frequent, preemptive form of interference with clinical programs. For example, the governor of Maryland imposed a requirement on the clinical program at the University of Maryland Law School and all other legal organizations receiving state funds that prior to filing any lawsuits against the state the entity receiving state funds must notify the state and attempt to resolve the matter without initiating litigation in court. ${ }^{48}$ This requirement trumps the desires of clinic clients or the litigation strategies of their lawyers. The Bureau of Prisons has taken a similar and more absolute approach by conditioning law school clinics' receipt of federal funds for prison legal assistance programs with a condition that the law school clinics shall not sue the United States or any employee of the United States. ${ }^{49}$ The Bureau of Prisons' approach effectively bans laws schools accepting funds to provide legal assistance to prisonerclients seeking to use litigation against the federal government or its employees no matter how blatant the alleged violation of prisoners' legal rights. These types of funding restrictions obviously apply to all legal service providers and are broader than restrictions targeted solely to clinical programs.

Some of the most prolonged attacks on clinical programs came in response to work of environmental law clinics. The longest series of attacks were those attacks aimed at the University of Oregon Law School's Environmental Law Clinic starting in 1981 and continuing through the early 1990s. The timber industry and government officials exerted pressure on university officials to close the Environmental Law Clinic because of the clinic's involvement in forest conservation and endangered species cases. ${ }^{50}$ In response to the pressures, the President of the University of Oregon appointed a committee to study the clinic and its use of public funds, and in 1988 the committee issued a report finding that the clinic "fulfills its educational function extremely well, through its advocacy serving a proper social role." 51 Similarly, the Oregon Attorney General, responding to the request of a state legislator requesting an investigation into the propriety of state funds supporting the clinic's representation of clients in matters against governmental entities, found that the "University is acting for an educational purpose it is authorized to undertake even though there are benefits inuring to private parties." 52 Faced with continued attacks and proposed legislative action to cut-off state funding of the law school, the Environmental Law Clinic eventually moved all litigation activities outside of the law school to a not-for-profit environmental law center. ${ }^{53}$

In more recent years, there were highly publicized attacks on the Environmental Law Clinic at Tulane University Law School starting in 1993 and continuing until 1998. In 1993, the governor of Louisiana demanded that the president of Tulane University either "shut up [the director] or get rid of" the director of the Environmental Law Clinic after the director made public comments

47 See Kuehn Ë Joy, supra note 5, at 1980 E̊ n. 41.

48 Robert Barnes, Gov. Schaefer Patches Spat With Lawyers, WASH. POST, July 23, 1987, at B5; Kuehn Eु Joy, supra note 5, at 1981 $\mathcal{G}$ n.44.

49 See, e.g., Kuehn E⿱ Joy, supra note 5, at 1981 n.45 (citing letters and interviews with faculty at the University of Southern California Law Center and Washington and Lee University School of Law).
50 See Joy $\mathcal{E}$ Weisselberg, supra note 6, at 534; Kuehn $\mathcal{E}$ Joy, supra note 5, at 1981-82.

51 University of Oregon School of Law, Report of the Ad Hoc Study Committee for the Environmental Law Clinic 15 (Nov. 30, 1985) (on file with author).

52 Oregon Attorney General OP-5498 (July 11, 1983).

53 See Joy $\mathcal{B}$ Weisselberg, supra note 6, at 534; Kuehn Eु Joy, supra note 5, at 1982. 
critical of the governor's plan to reduce state taxes on businesses generating hazardous waste. ${ }^{54}$ The governor threatened to pull state support for a university building project, deny state educational assistance to residents attending Tulane, and prohibit Tulane medical schools students from working in state hospitals. ${ }^{55}$ When the president of Tulane did not interfere with the clinic director's actions, the head of the Louisiana Department of Environmental Quality asked the Louisiana Supreme Court to review whether the clinic was complying with the state's student practice rule. ${ }^{56}$ That effort also failed, and the Louisiana Supreme Court found no reason to exercise oversight over the clinic. ${ }^{57}$

Several years later in 1997, when the Tulane Environmental Law Clinic undertook to represent a primarily low-income, minority community's opposition to a chemical plant, another governor, other state officials, and business interests sought to derail the clinic's representation in the matter. ${ }^{58}$ At first, the attacks involved public criticism, threats to revoke the tax-exempt status of the private non-profit law school, proposals to deny the university state educational trust fund money, and an orchestrated effort to stop charitable donations to the university. ${ }^{59}$ Some Louisiana employers even refused to interview or employ Tulane students as a way of increasing pressure on the university and law school. ${ }^{60}$ When none of these pressure tactics proved successful at stopping the clinic's representation of its clients, the government officials and business groups succeeded in persuading a majority of the elected justices to the Louisiana Supreme court to impose severe restrictions on the student practice rule aimed at preventing future representation of community groups. ${ }^{61}$ The amended rule imposes very restrictive income guidelines for clinic client eligibility, requires that at least $51 \%$ of an organization's members must meet the guidelines, prohibits contact with potential clients through community education or other outreach efforts, and

54 Michael Dehncke, Life in Louisiana, TULANE LAW SCHOOL DICTA (New Orleans, La.), Oct. 25, 1993, at 1 (quoting Governor Edwin Edwards of Louisiana) (on file with author).

55 Id.

56 Letter from Kai David Midboe, Secretary, Louisiana Department of Environmental Quality, to Pascal F. Calogero, Jr., Chief Justice, Louisiana Supreme Court (Oct. 15, 1993) (on file with author). See also Bob Anderson, "Politics" Prompted Protest of TU Law Clinic, Official Says, ADVOCATE (Baton Rouge, La.), Oct. 19, 1993, at 1B.

57 Letter from Pascal F. Calogero, Jr., Chief Justice, Louisiana Supreme Court, to Kai David Midboe, Secretary, Louisiana Department of Environmental Quality (Nov. 18, 1993) (on file with author). See also, Bob Anderson, High Court Rejects Midboe Request on Law Clinic Restraints, ADVOCATE (Baton Rouge, La.), Feb. 4, 1994, at 12C.

58 See Joy, supra note 6, at 243-47.

59 See id.

60 See Kuehn $\mathcal{E}$ Joy, supra note 5, at 1893 n.58 and accompanying text. There have been reports that the prosecutor in Houston has discriminated against University of Houston law students who have participated in the law school's Innocence Network, a clinic that represents wrongfully convicted inmates.
See Rebecca Luczycki, DA Hiring Policies Questioned, NAT'L JURIST, Oct. 2002, at 27; John Suval, Innocence Lost, HOUSTON PRESS, July 4, 2002, at 13. The prosecutor's office denies that it discriminates against law students who have participated in the clinic. See id.

61 Various business groups sent letters to the Louisiana Supreme Court demanding that the Court investigate the Tulane Environmental Clinic and change the student practice rule. See Letter from Daniel L. Juneau, President, Louisiana Association of Business and Industry, to Pascal F. Calogero, Jr., Chief Justice, Supreme Court of Louisiana (Sept. 9, 1997) (on file with author); Letter from Erik F. Johnsen, Chairman, Business Council of New Orleans and the River Region, to Pascal F. Calogero, Jr., Chief Justice, Supreme Court of Louisiana (Sept. 9, 1997) (on file with author); Letter from Robert H. Gayle, Jr. President and Chief Executive Officer, The Chamber/New Orleans and the River Region, to Pascal F. Calogero, Jr., Chief Justice, Supreme Court of Louisiana (Sept. 9, 1997) (on file with author). The letter writing campaign seeking changes to the student practice rule was an idea generated at a meeting with Governor Mike Foster of Louisiana where business leaders were urged "to send a series of letters to the Louisiana Supreme Court." Shintech's Secret Backer, COUNTERPUNCH, Nov. 16-30, 1997, at 2, 2-3. 
prohibits clinic students from appearing in a representative capacity before a legislature. ${ }^{62}$ The restrictions make Louisiana's student practice rule the "most restrictive student practice rule in the nation." ${ }^{63}$ A challenge to the restrictions on constitutional grounds was rejected by the federal courts. ${ }^{64}$

After the attacks on the Tulane clinical program, there were highly publicized attacks on the University of Pittsburgh Environmental Law Clinic, for the representation of community groups that were seeking to block the sale of timber in a national forest in 2001, ${ }^{65}$ and for representation of a community organization raising environmental concerns over the plans for a new highway in 2002. ${ }^{66}$ The attacks on the clinic at the University of Pittsburgh involved state legislators and business groups, and the first set of attacks succeeded in convincing the state legislature to pass a budget measure, which the governor signed, prohibiting taxpayer funds to be used to support the Environmental Law Clinic. ${ }^{67}$ Relying on private funds, the clinic continued and experienced further attacks in which opponents, using the threat of cutting off all state aid for the public university, sought to have university officials fire the director and close the clinic. ${ }^{68}$ Although university officials originally took actions to force the clinic out of the law school, they abandoned giving into the political interference after the university's academic freedom and tenure committee found that the proposal to force the clinic to leave the law school infringed on academic freedom. ${ }^{69}$

Another recent attack on a clinical program has come from a state legislator, the local media, and others against the Civil Rights Project at the University of North Dakota for representing clients challenging a display of a monument of the ten commandments on city property. ${ }^{70}$ Among the

62 See La. Sup. Ct. R XX (1999).

63 Letter from Carl C. Monk, Executive Director, Association of American Law Schools, to Murphy J. Foster, Governor, State of Louisiana 1 (Aug. 21, 1998) (on file with author).

64 S. Christian Leadership Conference v. Supreme Court of La., 61 F.Supp. $2 d 499$ (E.D. La. 1999), aff'd, 252 F.3d. 781 (5th Cir.), cert. denied, 534 U.S. 995 (2001).

65 Senator Wants to Punish Pitt for Logging Suit, PA. L. WKLY., May 28, 2001, at 9; Jim Eckstrom, Scarnati Prepared to Hit U. Pittsburgh Where it Counts Budget, BRADFORD ERA (Bradford, Pa.), May 23, 2001. See also Kuehn Eु Joy, supra note 5, at 1985-86.

66 Don Hopey, Law Clinic at Pitt Feeling Pressure, PITTSBURGH POST-GAZETTE, Oct. 17, 2001, at B-1; Johnna A. Pro, Road Group Targets Law Clinic at Pitt, PITTSBURGH POST-GAZETTE, Aug. 24, 2001, at B-4. See also Kuehn Eु Joy, supra note 5, at 1986-88.

67 State Senator Gets Symbolic Rebuke of Pitt Professor, Associated Press Newswires, June 23, 2001, WESTLAW, PANEWS library.

68 Frank Irey Jr., Pitt Should Drop Client that Opposes Expressway, PITTSBURGH POST-GAZETTE, Sept. 19, 2001, at E-2 (letter to editor from the President, Mon Valley Progress Council). See also Kuehn E⿱ Joy, supra note 5, at 1986-87.
69 University of Pittsburgh Senate, Report of the Tenure and Academic Freedom Committee on the Environmental Law Clinic (Jan. 28, 2002) (on file with author); Don Hopey 8 Bill Schackner, Faculty Rips Pitt, Defends Law Clinic, PITTSBURGH POST-GAZETTE, Jan. 29, 2003, at B-1; Don Hopey $\mathcal{E}$ Bill Schackner, In Reversal, Pitt Decides to Keep Law Clinic Going, PITTSBURGH POSTGAZETTE, Mar. 15, 2002, at A-1.

70 See Chuck Haga, City is Sued to Remove Religious Monument: Fargo's Ten Commandments Plaque is at Issue, STAR TRIBUNE (Minneapolis, Minn.), Oct. 30, 2003, at 1A. The clinic represented citizens objecting to a ten commandment monument on city property as constituting the government's endorsement of religion in violation of the First Amendment of the United States Constitution, which states: "Congress shall make no law respecting an establishment of religion... . U.S. Const. amend. I. The clinic's representation of the clients in the controversial case prompted a state legislator to seek an investigation charging that the clinic's representation against the municipality was "a totally inappropriate use of public funds." Tony Lucia, U. North Dakota Law School Criticized for Taking Ten Commandments Case, UNIVERSITY WIRE, Sept. 15, 2003. A local newspaper supported the representative's efforts and called for the "university to rein in its law school." UND Should Rein In Its Law School, BISMARK TRIBUNE, Sept. 4, 2003, A4. Responding to criticisms, the interim dean of the law school stated 
tactics employed to stop the clinic from representing its clients was a request from the state lawmaker for the North Dakota Attorney General to investigate whether the state supported law school's clinic could represent individuals with claims against the state or its political subdivisions. ${ }^{71}$ The Attorney General issued an opinion finding that the clinic was acting legally and that "the legal clinic's representation of the client does not constitute the state or University's position on the underlying subject matter."72 The Attorney General also found that "the North Dakota Rules of Professional Conduct support the principle that controversial or unpopular clients should not be denied legal representation." 73

After the Attorney General issued his opinion, someone who had made "several harassing statements" toward the clinic director and the clinical program because of the ten commandment case sued the director and the clinic alleging viewpoint discrimination when the clinic declined to provide legal assistance to him. ${ }^{74}$ The clinic declined to represent him due to lack of time and resources, and also because of curricular and ethical reasons. The clinic director "determined that the clinic would not be able to establish an effective client-attorney relations with him based on . . . [his] antagonistic position against her personally and the clinical program." ${ }^{\prime 75}$ Although his case was dismissed at the federal district court level at the beginning of the litigation, the court of appeals has ruled that the district dismissed the case prematurely. ${ }^{76}$ Reconsideration of this ruling has been sought, and the matter will be remanded to the district court for additional proceedings if the court of appeals does not reconsider the matter.

This brief history into the nature and types of attacks on clinical programs is part of what one commentator, writing in 1984, characterized as "a broader war on legal services and public interest legal groups" in the United States. ${ }^{77}$ That connection between the attacks on public interest lawyers and clinical programs has been repeatedly made since that time by others, and the next section examines some of the larger issues of access to justice and attacks on lawyers serving those otherwise unable to afford legal assistance in order to place the attacks on clinical programs in context.

that the law school did not seek out controversial cases, "[b] ut as attorneys, we're not supposed to refuse to take cases just because they're controversial. When you think about it, that would have a devastating effect on a person's ability to attain an attorney." Brenden Timpe, N.D. Attorney General Sides with U. North Dakota Law School's Representation, UNIVERSITY WIRE, Sept. 30, 2003.

71 N.D. Attorney General Op. 2003-L-42 (Sept. 26, 2003).

72 Id.

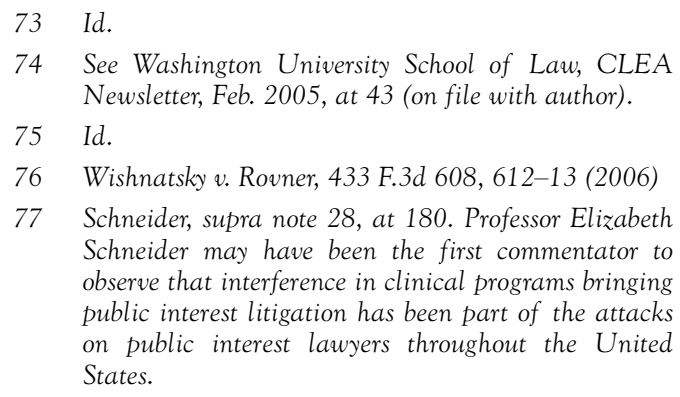

74 See Washington University School of Law, CLEA Newsletter, Feb. 2005, at 43 (on file with author). 75 Id.

76 Wishnatsky v. Rovner, 433 F.3d 608, 612-13 (2006)

77 Schneider, supra note 28, at 180. Professor Elizabeth Schneider may have been the first commentator to observe that interference in clinical programs bringing public interest litigation has been part of the attacks on public interest lawyers throughout the United States. 


\section{ACCESS TO JUSTICE AND ATTACKS ON PUBLIC INTEREST LAWYERS}

Access to the courts is generally accepted to be a precondition for justice, and equal access to justice and equality of justice are among the most fundamental principles of a democratic society. ${ }^{78}$ Individuals and groups customarily must have lawyers representing them to assert rights before courts and administrative agencies and without lawyers to advocate for them their rights are usually lost. ${ }^{79}$ Indeed, fairness in a legal proceeding assumes a meaningful opportunity to be heard, and the right to be heard is often an empty promise if legal representation is not available. ${ }^{80}$

Despite the promises of equal justice and access in the United States, the poor are not entitled to the assistance of a lawyer if they cannot afford to hire one except in criminal cases. ${ }^{81}$ Those individuals and families with incomes at or below $125 \%$ of the poverty level as defined by the federal government are eligible for federally funded legal services through the Legal Services

78 These principles are repeated often in the United States, and underlie the motto "Equal Justice Under Law," which is inscribed above the entrance to the United States Supreme Court Building. Former United States Supreme Court Justice Lewis Powell explained, "Equal justice under law is not just a caption on the facade of the Supreme Court building. It is perhaps the most inspiring ideal of our society. .. It is fundamental that justice should be the same, in substance and availability, without regard to economic status." Scott S. Brinkmeyer, Are the Doors to the Courthouse Really Open?, 83 MICH. B.J. 12, 13 (2004) (quoting Lewis Powell, Address to the ABA Legal Services Program, ABA Annual Meeting (1976)). "If we are to keep our democracy, there must be one commandment: Thou shalt not ration justice." In re Smiley, 330 N.E. $2 d$ 53, 63 N.Y. 1975) (internal quotations omitted) (quoting Learned Hand, Address Before the Legal Aid Society of New York (1951)). [footnote to be completed with citation to international sources]

79 Professor Edgar S. Cahn Eु Jean C. Cahn have explained: The lawyer's function is essentially that of presenting a grievance so that those aspects of the complaint which entitle a person to a remedy can be communicated effectively and properly to a person with power to provide a remedy. . . . [I]t is altogether possible that for many a remedy is available if the grievance is properly presented. ... Edgar S. Cahn $\mathbb{E}$ Jean C. Cahn, The War on Poverty: A Civilian Perspective, 73 YALE L.J. 1317, 1336 (1964).

80 "At the very heart of our recognition of the right to counsel elsewhere has been our articulated conviction that the right to be heard would be of little avail of it did not comprehend the right to be heard by counsel." Smiley, 330 N.E. $2 d$ at 59 (Jones, J., dissenting) (internal quotations omitted) (quoting People ex rel. Menechino v. Warden, 267 N.E. $2 d$ 238, 241 (N.Y. 1971)).

81 The Sixth Amendment to the U.S. Constitution provides: "In all criminal prosecutions, the accused shall enjoy the right to ... be informed of the nature and cause of the accusation; to be confronted with the witnesses against him ... and to have the Assistance of
Counsel for his defense." U.S. Const. amend. VI, 1. The landmark case of Gideon v. Wainwright interpreted this language to mean that defendants have a right to counsel at all criminal trials where incarceration was possible. Gideon v. Wainwright, 372 U.S. 335, 344 (1963) ("Any person hauled into court, who is too poor to hire a lawyer, cannot be assured a fair trial unless counsel is provided for him."). Subsequent to the Gideon decision, the Supreme Court refused to extend the constitutional right to counsel in civil matters holding that the due process clause of the Fourteenth Amendment requires the appointment of counsel only where denial would prove "fundamentally unfair." Lassiter v. Dept. of Social Services, 452 U.S. 18, 33 (1981). The fundamental fairness test in Lassiter requires an inquiry into "the private interests at stake, the government's interest, and the risk that the procedures used will lead to erroneous decisions." Id. at 27. Few judges have been reversed for finding that counsel is not required under this test. Deborah L. Rhode, The Constitution of Equal Citizenship for a Good Society: Access to Justice, 69 FORDHAM L. REV. 1785, 1798 (2001).

In many states, however, case law, legislation, or constitutional provisions guarantee the assistance of counsel in some criminal matters where incarceration is not possible, some quasi-criminal matters, or some civil proceedings. See, e.g., In re Miller, 585 N.E. $2 d$ 396, 400 (1992) (holding that involuntary commitment is a sufficient deprivation of liberty requiring at lawyer for due process protection); In re Adoption of R.I., 312 A.2d 601, 603 (Pa. 1973), cert. denied, 429 U.S. 1032 (1977) (holding that an individual is entitled to representation by counsel when contesting proceeding to terminate parental rights). See Robert L. Spangenberg \&8 Marea L. Beeman, Toward a More Effective Right to Assistance of Counsel: Indigent Defense Systems in the United States, 58 LAW $\&$ CONTEMP. PROBS. 31, 31 (1995); Randolph N. Stone, The Role of State Funded Programs in Legal Representation of Indigent Defendants in Criminal Cases, 17 AM. J. TRIAL ADVOC. 205, 207 (1993). 
Corporation (LSC), ${ }^{82}$ but the LSC estimates that it handles only some of the legal problems for approximately $20 \%$ of those eligible. ${ }^{83}$ Professor David Luban estimates that there are only 4000 legal-aid lawyers plus an estimated 1000 to 2000 additional lawyers representing the poor in the United States. ${ }^{84}$ As a result, "[a]n estimated four-fifths of the legal needs of the poor, and the needs of two-to three-fifths of middle-income individuals, remain unmet." 85

In the context of the very limited legal services for the poor in the United States, efforts to limit or prohibit the legal services provided by clinical programs are particularly troubling, and they are part of the same attacks and restrictions experienced by others providing legal assistance to the poor. ${ }^{86}$ Similar attacks and often more serious restrictions have been directed to LSC and aid to public interest lawyers through Interest on Lawyers Trust Accounts (IOLTA) programs. A brief review of the attacks on LSC and IOLTA demonstrates the similarity with the attacks on clinical programs.

\section{A. Restrictions on LSC Recipients}

Federal funding restrictions on the LSC have long prohibited the LSC from providing representation to clients on controversial issues such as abortion, but in 1996 the United States Congress enacted even greater restrictions. Today, LSC-funded lawyers may not participate in any class action litigation, may not collect court-awarded attorney's fees, litigate on behalf of anyone incarcerated, or represent various classes of non-citizens, many of who have legal immigration status. ${ }^{87}$ In addition, LSC-funded lawyers may not be involved in election redistricting cases, evictions from public housing of persons allegedly involved with drugs, or attempts to influence

82 See Legal Services Corp., Serving the Civil Legal Needs of Low-Income Americans 1 (2000), at http://www.lsc.gov/pressr/EXSUM.pdf [hereinafter Serving Civil Legal Needs] (last visited June 17, 2005). The Legal Services Corporation (LSC) was created by the federal government in 1974 and "charged by Congress 'to provide equal access to the system of justice in our Nation for individuals who seek redress of grievances' and 'to provide high quality legal assistance to those who would otherwise be unable to afford adequate legal counsel." Id. In 2000, approximately 34.5 million Americans lived in households with incomes below the poverty level, and an additional 10 million more had incomes between $100 \%$ and $125 \%$ of the poverty level, thereby making them eligible for LSC legal assistance. Id. at 12.

83 Nationwide Survey of the Civil Legal Needs of the Poor 4, in TWO NATIONWIDE SURVEYS: 1989 PILOT ASSESSMENTS OF THE UNMET LEGAL NEEDS OF THE POOR AND OF THE PUBLIC GENERALLY (American Bar Ass'n 1989).

84 David Luban, Taking Out the Adversary: The Assault on Progressive Public-Interest Lawyers, 91 CALIF. L. REV. 209, 211 (2003).

85 Deborah L. Rhode, Equal Justice Under Law: Connecting Principle to Practice, 12 WASH. U. J.L. Eु POL'Y 47, 47 (2003). See also Roger C. Cramton, Mandatory Pro Bono, 19 HOFSTRA L. REV. 1113 , 1121 (1991) ("But informed observers agree that there remains a tremendous unmet need, estimated at $75 \%$ to as much as $95 \%$ of the total legal needs of the poor.") In the United States, "approximately 35.8 million people lived below the poverty line in 2003, or about 12.5 percent of the population." Tyche Hendricks, Number Living in Poverty Grows as Middle-class Incomes Stay Flat, SAN FRANCISCO CHRON., Aug. 27, 2004, at A20. Various studies support the view that most of the legal needs of those living at or near the poverty level are not being met by the legal system in the United States. See, e.g., ALBERT H. CANTRIL, AGENDA FOR ACCESS: THE AMERICAN PEOPLE AND CIVIL JUSTICE 1-2 (American Bar Ass'n 1996) (presenting survey results of the nearly $20 \%$ of the households eligible for federally funded legal services); Legal Needs and Civil Justice: A Survey of Americans 23 (American Bar Ass'n 1994) (finding that the legal system does not address approximately $71 \%$ of the legal problems of low-income households).

86 See note 77 and accompanying text.

87 Serving Civil Legal Needs, supra note 82, at 2. Congress originally imposed a prohibition on litigation to challenge existing welfare laws, but the Supreme Court ruled that provision as viewpoint discrimination in violation of the First Amendment. Legal Servs. Corp. v. Velazquez, 531 U.S. 533, 547-48 (2001). Challenges of other restrictions on equal protection and due process bases failed. See Legal Aid Soc. of Haw. v. Legal Serv. Corp., 145 F.3d 1017 (9th Cir. 1998); Velazquez v. Legal Servs. Corp., 164 F3d 757 (2d Cir. 1999). 
government rulemaking or the enactment of laws. ${ }^{88}$ Those receiving LSC funds are also prohibited from using any nonfederal funds to fund any prohibited legal representation. ${ }^{89}$

Some of these restrictions also have the effect of making it more costly and time consuming for LSC lawyers to pursue certain claims. For example, the restrictions require LSC lawyers to litigate individual cases when a class action case would be more efficient, thus presenting LSC lawyers with the choice of engaging in redundant litigation or turning away the individual cases that would be most amenable to class action representation..$^{90}$ The ban on receiving attorney fees also deprives LSC offices of supplemental funds that could be used to represent more clients. When LSC lawyers do litigate in matters where attorney fees are possible, the Congressional ban on seeking attorney fees also removes some of the incentives for defendants to resolve cases quickly or to enter into settlement discussions because defendants will not have to pay reasonable attorney fees for the work done by the LSC lawyers representing successful clients.

As a result of the LSC restrictions, whole groups of otherwise income eligible persons with cognizable legal claims are denied legal representation and an opportunity to have their claims presented. Even those individuals who are not barred from receiving legal representation find that they cannot have a lawyer for certain types of legal problems, nor have a lawyer assist them in asking legislators or other government officials from creating systematic solutions and preventative measures to reoccurring problems through changes in the laws and rules.

Because of the restrictions on the LSC and the LSC's ability to assist only a small fraction of those who are income eligible because of inadequate funding, other forms of legal assistance for the poor become even more importation. But, the attacks on public interest lawyers have extended to the other means of providing lawyers for the poor.

\section{B. Legal Challenges to IOLTA Programs Funding Civil Legal Services}

IOLTA programs are an important source of funding for public interest lawyers providing civil legal services to the poor in the United States. Clients funds that are too small to be placed in individual trust accounts, or held for too short of a period of time to earn interest for individual clients after paying bank fees, are placed in pooled IOLTA accounts where the funds generate interest that is used to support non-governmental organizations providing public interest lawyers. ${ }^{91}$

88 Serving Civil Legal Needs, supra note 82, at 2.

89 Id.

90 Professor David Luban has described this dilemma and suggests that it is more likely that rather than litigate numerous individual cases, LSC lawyers will turn those cases down that creating a "perverse result: the more poor people a legal problem affects, the less likely they are going to find a lawyer to represent them." Luban, supra note 84, at 223.

91 The fiduciary obligations of a lawyer require that the lawyer hold client funds separate from the lawyer's funds. See, e.g., MODEL RULES, supra note 22, at R.1.15(a) ("A lawyer shall hold property of clients or third persons that is in a lawyer's possession in connection with a representation separate from the lawyer's own property."); Model Code, supra note 22, at DR 9-102 ("All funds of clients paid to a lawyer or law firm, other than advances for costs and expenses, shall be deposited in one or more identifiable bank accounts maintained in the state in which the law office is situated and no funds belonging to the lawyer or law firm shall be deposited therein . . . ."); RESTATEMENT (THIRD) OF THE LAW GOVERNING LAWYERS § 44(1) (stating that a lawyer must hold property in which a client has or claims an interest "separate from the lawyer's property"); National Legal Aid Eु Defender Association, Fact Sheet on Interest on Lawyers' Trust Accounts (IOLTA), at http://www.nlada.org/DMS /Documents/1011300749.75/-Fact\%20 Sheet $\% 20$ on $\% 20 I O L T A . P D F$ (last visited June 17, 2005) (describing IOLTA accounts).

IOLTA programs were made possible by changes in banking laws and regulations that permitted the pooling of funds into a single interest bearing account 
There are IOLTA programs in all fifty states and the District of Columbia, and together they rank second only to the LSC in funding legal services for the poor. ${ }^{92}$ Yet, there have been a number of legal challenges to IOLTA programs funding civil legal services.

Although there have been attacks on IOLTA programs since the $1980 \mathrm{~s},{ }^{93}$ the Washington Legal Foundation (WLF), known for litigating free-enterprise and property rights issues, has been the principal opponent to IOLTA in recent years. ${ }^{94}$ In a succession of cases litigated in several states, ${ }^{95}$ WLF challenged IOLTA programs as an impermissible "taking" of private property under the United States Constitution. ${ }^{96}$ As a result of the litigation to date, the United States Supreme Court ruled in one case "that the interest income generated by funds held in IOLTA accounts is the 'private property' of the owner of the principal." 97 In a second and more recent case, the Court held that even if the IOLTA program was a per se taking, the taking was for a legitimate public use and "compensation is measured by the owner's pecuniary loss - which is zero." 98 The Court reached the conclusion that the WLF clients had no cognizable pecuniary loss based on the lower court's finding that if the individual client funds were substantial enough "to make any net return, they would not be subject to the IOLTA program." 99

The Court's decisions in the WLF cases still leave open the question of whether or not IOLTA programs violate the First Amendment rights of those challenging the programs because their property generates the funds supporting litigation with which they may disagree. ${ }^{100}$ In a dissenting opinion, one Supreme Court Justice noted that the First Amendment issue had not yet been addressed by the Court and he predicted: "One constitutional violation (the taking of property) likely will lead to another (compelled speech). These matters may have to come before the Court in due course." 101 In a statement issued after the last Supreme Court decision, the WLF stated that

that were adopted in the early 1980s. Prior to this time, small or short-term client funds were kept in noninterest bearing accounts and the banks benefited from the use of the funds held interest free. See Fact Sheet on Interest on Lawyers' Trust Accounts (IOLTA), supra. When a client's funds are substantial enough to net interest after the payment of banking fees, lawyers should place those funds in a separate trust account for the benefit of the client.

92 IOLTA programs generated over $\$ 139$ million in 1999. Fact Sheet on Interest on Lawyers' Trust Accounts (IOLTA), supra note 91. The budget for LSC was \$335 million in 2004. National Legal Aid Eु Defender Association, President's FY 2005 Budget Request Remains the Same, at http://www.nlada.org/Civil/NLADA_News/2004030130394725 (last visited June 20, 2005).

93 See, e.g., Luban, supra note 84, at 227 Eु n.70 (describing and citing early litigation against IOLTA programs).

94 The Washington Legal Foundation (WLF) also sided with the business interests attacking the Tulane Environmental Clinic. See infra note 104 and accompanying text.

95 See Luban, supra note 84, at 228-34 (describing Washington Legal Foundation litigation against
IOLTA in Massachusetts, Texas, and Washington). Washington Legal Foundation (WLF) literature states that WLF "has been battling IOLTA programs on behalf of property owners since 1991." Washington Legal Foundation, Litigation Update: Supreme Court Rejects Challenge to Confiscatory IOLTA Programs (Apr. 4, 2003), at http://wwww.wlf.org/upload/4-403IOLTA.pdf (last visited June 20, 2005).

96 The Takings Clause of the Fifth Amendment states "nor shall private property be taken for public use, without just compensation." U.S. Const. amend V.

97 Phillips v. Washington Legal Found., 524 U.S. 156, 172 (1998).

98 Brown v. Legal Found. of Wash., 538 U.S. 216, 240 (2003). See also Marcia Coyle, Battle over IOLTA Could be Renewed: Using Funds for Indigent Clients Might be Seen as "Compelled Speech", NAT'L. L.J., Mar. 31, 2003, at A5.

99 Brown v. Legal Found. of Wash., 538 U.S. at 240 (citing Washington Legal Foundation v. Legal Foundation of Washington, No. C97-0146C (WD Wash., Jan. 30, 1998), App. to Pet. for Cert. 94a).

100 Id. at 228 (stating that one of the claims raised by the WLF was a First Amendment issue).

101 Id. at 253 (Kennedy, J., dissenting). 
"WLF is consulting with its clients to determine whether they wish to continue to pursue their First Amendment claims.",102

Whether WLF challenges to IOLTA on First Amendment grounds will materialize remains to be seen. Even some supporters of the WLF's Takings Clause challenges acknowledge that a successful First Amendment challenge would be very difficult. ${ }^{103}$ Still, WLF and others have been challenging IOLTA programs almost from their inception, and there is no clear sign that litigation against IOLTA funding civil legal services will cease. Indeed, the WLF's attack on public interest lawyers appears to be broader than just attacks on IOLTA programs. For example, the WLF sided with the business groups seeking changes in the Louisiana student practice rule to stop the Tulane Environmental Clinic from representing community groups by filing an amicus brief in federal court arguing that the restrictions on clinic students' ability to represent indigent clients are appropriate. ${ }^{104}$

\section{THE LEGACY OF POLITICAL INTERFERENCE ON CLINICAL PROGRAMS}

The history and description of political interference in clinical programs demonstrate that in some instances restrictions have been imposed that foreclose particular clinical programs from representing certain clients, advancing some legal claims for clients, or engaging in litigation strategies against some parties. ${ }^{105}$ These are the same types of restrictions imposed on the LSC. The restrictions on clinic case and client selection also have the effect of essentially cutting off funding for the legal representation to the poor, one of the goals of challenges to IOLTA programs.

In addition to the formal restrictions that have been imposed on some clinical programs, commentators suggest that perhaps a greater number of clinical programs have imposed their own internal restrictions and "have refused to represent certain controversial cases or clients because of fears that taking such cases could result in threats to their continued operation." 106 For example, commenting on the attacks to the Tulane Environmental Law Clinic, the director of one of the

102 Litigation Update: Supreme Court Rejects Challenge to Confiscatory IOLTA Programs, supra note 95.

103 Responding to the Court's rejection of the Takings Clause claims, James Burling, who filed an amicus brief on behalf of the Pacific Legal Foundation supporting the WLF in Brown v. Legal Foundation of Washington, stated that it "would be tough to raise a First Amendment challenge to" using IOLTA funds for civil litigation "like divorces and landlord-tenant problems." Coyle, supra note 98, at A5. He stated, however: "If you're talking about money used for impact litigation - to make policy decisions - you might be on more fertile ground." Id.

104 See Brief for Amicus Curiae Washington Legal Foundation and Economic Freedom Law Clinic, S. Christian Leadership Conference, La. Chapter v. Supreme Court of La., 252 F.3d 781 (5th Cir. 2001). The Washington Legal Foundation (WLF) describes their amicus brief in this case as part of its project Reigning in the Plaintiffs' Bar. See Washington Legal
Foundation, Reining in the Plaintiffs' Bar, at http://www.wlf.org/Litigating/casedetail.asp?detail=4 7 (last visited June 20,2005). WLF literature states that the as part of its Reining in the Plaintiffs Bar project it "has litigated to ensure that court-awarded fees are kept within reasonable limits, that public funds are not used to support unwarranted litigation, and that appropriate sanctions are imposed on attorneys who file frivolous suits or otherwise abuse the public trust." Id. None of these issues are present in the limits imposed on clinical programs in Louisiana. See supra notes 62-63 and accompanying text. In addition to its amicus brief, the WLF took out an advertisement in the New York Times criticizing clinical programs for the clients clinics represent. See Daniel J. Popeo, A One-Sided Paper Chase, advertisement, N.Y. TIMES, Feb. 20, 2000, at A23.

105 See supra Part I.B. for a discussion of restrictions that have been imposed on some clinical programs.

106 Kuehn Eु Joy, supra note 5, at 1989 Eु n.87. 
largest clinical programs in the United States reportedly stated that her program is "very careful about the cases it accepts" and that it "tries to avoid high-profile cases." 107

It is important to recognize, however, that most of the work of clinical programs in the United States involves the representation of individual clients in matters that have been described as "oneclient-at-a-time, more-or-less routine, direct-client representation." 108 In addition, some of the cases that triggered political attacks, such as prison litigation to gain access to library resources for inmates, ${ }^{109}$ may not have seemed like a controversial case when the clinic first undertook the representation. What makes a case controversial often has less to do with the case itself, and more to do with the reaction of a government official, opposing counsel, or an interested party. The breadth of the attacks on clinical programs, in both public and private law schools, for the different types of cases handled "demonstrates that no law clinic program is immune from such assaults." 110

Still, those clinical programs that intentionally take some challenging cases that may be controversial in order to provide clinic students with the exposure to more complex legal issues run a greater risk of being targeted for political interference. This is particularly troubling because of the long history in the Unites States of published court decisions in which clinical law students and faculty represented individuals with regard to important issues such as access to the courts in forma pauperis, ${ }^{111}$ challenging discrimination in radio broadcast licensing, ${ }^{112}$ sex discrimination in employment, ${ }^{113}$ supporting municipal nuisance ordinances, ${ }^{114}$ asserting the civil rights of the homeless, ${ }^{115}$ representing inmates in civil rights cases against municipalities and police for intentionally violating their Miranda rights, ${ }^{116}$ and other important cases. ${ }^{117}$

It is undeniable that political interference in clinical programs in the United States has taken its toll not only on those clinics that have been targeted but also on other law school clinics. The public attacks on law school clinical programs represent just a small percentage of the less well publicized

107 Caille M. Millner, Harvard U. Law School Watches Court Case About Legal Assistance, UNIVERSITY WIRE, Mar. 9, 1999 (paraphrasing Jeanne Charn's statements reacting to the attacks on the Tulane Environmental Law Clinic). Jeanne Charn, Lecturer in Law and Director of the Hale and Dorr Legal Services Center for Harvard Law School, one of the largest law school clinical programs in the United States, is also quoted as stating, "The best way for students to get clinical education is to avoid tackling controversial cases." Id. In the article, Charn does not explain if her clinical program attempts to screen out controversial cases for purely pedagogical reasons, or if the aversion to controversial cases is related to some fear of possible interference with the clinical program. See id.

108 Luban, supra note 84, at 236.

109 See supra note 45 and accompanying text.

110 Kuehn Eु Joy, supra note 5, at 1992.

111 California Men's Colony, Unit II Men's Advisory Council v. Rowland, 939 F.2d 854 (9th Cir. 1991), rev'd, 506 U.S. 194 (1993) (Post-Conviction Project, University of Southern California).
112 National Black Media Coalition v. F.C.C., 822 F.2d 277 (2d Cir. 1987) (Media Law Clinic, New York University School of Law).

113 Congregation Kol Ami v. Chicago Comm'n on Human Relations, 649 N.E.2d 470 (Ill. App. Ct. 1995) (Edwin F. Mandel Legal Aid Clinic, University of Chicago).

114 Inter Urban Bar Assoc. of New Orleans v. City of New Orleans, 652 So.2d 1038 (La. App. Ct. 1995 (Tulane Environmental Law Clinic, Tulane Law School).

115 Johnson v. Bd. of Police Comm'rs, 351 F. Supp. $2 d$ 929 (E.D. Mo. 2004) (Civil Justice Clinic, Washington University in St. Louis \& St. Louis University Legal Clinic); Streetwatch v. Nat'l R.R. Passenger Corp., 875 F. Supp. 1055 (S.D.N.Y. 1995).

116 California Attys. for Crim. Justice v. Butts, 195 F.3d 1039 (9th Cir. 1999) (Center for Clinical Legal Education, Boalt Hall School of Law, University of California, Berkeley).

117 The cases listed in footnotes 112-117 represent a small number of reported cases in which clinical programs have represented clients. 
questions clinical programs more frequently face over the clients and cases clinics represent. ${ }^{118}$ Each phone call or letter to a clinic director, law school dean, or university official questioning a clinic's involvement in the case raises the possibility that the questions may turn into pressure to force the clinic to end its representation of a client in need, to refuse to represent such clients in the future, or to avoid representing any client against more powerful parties such as governmental entities or large businesses. Both the public, prolonged attacks on clinical programs and the more frequent phone calls and letters questioning clinics' representation of clients send a message to clinical programs that representation of almost any client, and particularly unpopular clients or controversial causes, may come at a cost. When viewed in connection with the attacks on the LSC and IOLTA, the political interference in clinical programs also demonstrate that those who ultimately suffer the most are the potential clients whose rights are being lost due to the lack of legal representation. ${ }^{119}$

In many ways, interference with clinical programs operate like SLAPP suits - Strategic Lawsuit Against Public Participation. In SLAPP suits, citizens in the United States protesting corporate policies, business developments, or even complaining against teachers or police, may face lawsuits for defamation or tortuous interference with business. Although nearly all SLAPP suits are dismissed before trial, the SLAPP suits are designed to intimidate opposition by causing those protesting to incur large legal fees and to fear possible personal liability. ${ }^{120}$ Because of fear of SLAPP suites, citizen participation is often stifled. The ultimate aim of those interfering with clinical programs is also one of intimidation - to cause clinical faculty, law school deans, and university administrators to drop cases and to avoid taking cases against certain businesses or governmental entities. To the degree that clinical faculty screen out cases that would otherwise make good clinic cases because faculty fear that the cases may be trigger interference, the faculty succumb to ultimate aim of those seeking to block legal representation for anyone challenging their actions.

Experience in the Unites States has shown that cultivating support for clinical programs among non-clinical faculty and law school deans is key to withstanding political interference. Such support generally flows from explaining what the clinic does, and how cases are selected based on pedagogical values and, when it is a goal of a clinic, the legal needs of the community. It is also good to cultivate contacts with the local media, and to explain to them the important work that the clinic is doing. It is not unusual in the United States for clinical programs to be the focus of human interest stories. It is best to have the support for clinical programs in place prior to an instance of interference, and it is important to resist the interference. Pointing out that the interference is seeking to deny access to the courts for those unable to hire attorneys is often a hook that some in the media use to characterize the conflict.

The full extent of direct and indirect pressure on clinical faculty to restrict their client and case selection is not known, but there are sufficient examples to illustrate that this is a problem, at least in the United States. Whether and to what extent clinical faculty in other countries face or will face

118 See, e.g., Joy $\mathbb{E}$ Weisselberg, supra note 6, at 531 E⿱ n.1 (stating that many who teach in clinical programs receive inquires from people outside of the law school questioning "why 'the law school' is involved in a particular case”); Kuehn E⿱ Joy, supra note 5, at 1989 $n .88$ (documenting several instances of complaints to law school deans and pressure on university officials to order clinical programs to withdraw from litigation).

119 There are no reported instances of clinical programs or their clients being targeted by countersuits, often referred to as SLAPP suits - strategic

120 See Luban, supra note 84, at 219. 
similar issues of political interference in the clients they represent are questions that existing scholarship and news reports do not answer. ${ }^{121}$ In contrast to the United States, the Australian states, Canada, New Zealand, European countries, and some other nations have different schemes for providing legal assistance to individuals in civil matters which may make legal counsel more available for lower income persons than it is in the United States. ${ }^{122}$ The greater availability of legal counsel to those unable to hire attorneys in other countries may possibly mute or tend to discourage attacks on clinical programs providing representation to those with low incomes. There may also be some different cultural norms against attacking access to the courts in other countries that may prevent some attacks on clinical programs. Nevertheless, clinical faculty in other countries may find that understanding the experience of attacks on clinical programs in the United States will be helpful in addressing this issue should their clinical programs become the targets of similar political attacks.

\section{CONCLUSION}

An essential cornerstone of any society based on the rule of law is access to the courts. ${ }^{123}$ In a functioning democracy, access to the courts is access to justice, and an individual's right to sue and to defend against actions taken by the state or others becomes "the right that protects all other rights." 124 Thus, in many countries the most pressing issues are the fairness of the judicial system and the allocation and delivery of legal services - conditions necessary for an effective rule of law.

The political interference in clinical programs affects the ability of law school clinics to provide access to the courts to traditionally underrepresented individuals, families, and groups. When efforts to limit the types of clients or causes clinical programs are successful, they effectively close the courthouse doors to those unable to find other legal representation. In this way, political interference in clinical programs is a maneuver designed to subvert the normal processes of the rule of law.

Political interference in clinical programs, like the attacks on other programs providing lawyers for the low income persons and community groups in the United States, has been called a "silencing doctrine" or "extralegal strategy" because these attacks are deliberate attempts to deny those

121 This author was unable to find scholarly articles, reports, or news items discussing political interference in clinical programs outside of the United States. However, conversations with clinical faculty from Australia, Canada, Great Britain, and Israel have disclosed instances of varying degrees of interference with clinical programs.

122 See, e.g., Earl Johnson, Jr., The Right to Counsel in Civil Cases: An International Perspective, 19 LOY. L.A. L. REV. 341, 342 (1985) (citing the laws and constitutional provisions establishing the right to legal counsel in civil cases in countries around the world); Lua Kamal Yuille, No One's Perfect (Not Even Close): Reevaluating Access to Justice in the United States and Western Europe, 42 COLUMBIA J. TRANSNAT'L L. 863, 878-85 (2004) (describing civil legal assistance as a "right" in most European countries). Although some countries may describe civil legal assistance as a right, or make legal assistance in civil matters more available to low income persons than it is in the United States, providing adequate legal representation to persons unable to pay for lawyers is a world-wide issue.

123 See, e.g., Jégo-Quéré v. Commission, Ct. First Instance, Case No. T-177/01 (2002) (stating that "it should be borne in mind that the Court of Justice itself has confirmed that access to the courts is one of the essential elements of a community based on the rule of law"); DAVID LUBAN, LAWYERS AND JUSTICE: AN ETHICAL STUDY 256-66 (1988) (arguing that access to the courts is necessary to promote the legitimacy of a government).

124 Deborah L. Rhode, Professionalism in Law Schools, 27 FLA. ST. U.L. REV. 193, 199 (1999). 
unable to hire attorneys the opportunity to have access to the courts. ${ }^{125}$ These efforts seek to transcend the normal legal processes available to all in theory by limiting access to justice in reality only to those who can afford to hire attorneys. When these efforts to limit access to the courts are successful, the rule of law is eroded.

Law school clinical programs play important roles in educating law students and in providing access to the courts for many in need. Because law school clinics are places where law students often receive their first exposure to the practice of law, the clinic law office should be a model ethical law office, and the clinical faculty and other lawyers in those offices should model the highest ethical practice and norms of the legal profession. By evaluating potential cases on the legal merits and their pedagogical values, and by agreeing to represent clients even when a case may become controversial, clinical faculty and their programs can model the highest ideals of legal profession.

125 Luban describes silencing doctrines as "statutes, rules, and judicial decisions that allow opponents to attack the funding or restrict the activity of their adversaries' advocates." Luban, supra 84, at 220. I have previously discussed the attacks on the Tulane Environmental Clinic, and the successful efforts to persuade the elected judges of the Louisiana Supreme Court to adopt restrictive student practice rules, as extralegal because they prevent "opposing parties from having meaningful access to the courts." Joy, supra note 6, at 272 n.188 and accompanying text. Professor Lynn LoPucki and Walter Weyrauch coined the term "extralegal strategies" to describe "strategic effort is devoted to extralegal means of deterring those entitled to legal remedies from suing or from continuing suits already filed." Lynn M. LoPucki Ë Walter O. Weyrauch, A Theory of Legal Strategy, 49 DUKE L.J. 1405, 1461 (2000). 